\title{
Hyaluronate for the Treatment of Ankle Osteoarthritis
}

\author{
Shu-Fen Sun ${ }^{1,2}$, Chien-Wei Hsu1,2, \\ Yi-Jiun Chou ${ }^{1}$, Yu-Nong Wang ${ }^{1}$ and Mei-Chia Chou ${ }^{1}$ \\ ${ }^{1}$ Kaohsiung Veterans General Hospital, \\ ${ }^{2}$ National Yang-Ming University School of Medicine, \\ Taiwan
}

\section{Introduction}

Ankle osteoarthritis (OA) is a degenerative joint disease that can cause substantial pain, muscle weakness and functional limitations. Due chiefly to its post-traumatic origin and appearance in young patients, ankle OA has a high impact on socioeconomics and patients' quality of life. Approximately $6 \%$ to $13 \%$ of all cases of OA involve the ankle joint (Thomas and Daniels, 2003). Recent research also identify that a larger number of patients are being diagnosed with ankle OA (Saltzman et al, 2005). Currently, no curative therapy is available for OA, and thus the overall goals of management are to reduce pain and prevent disability. Treatment options include simple analgesics, nonsteroidal anti-inflammatory drugs (NSAIDs), weight reduction, physical and occupational therapy, activity modification, orthotic devices, shoe modifications, intraarticular corticosteroid injections, and surgery. Although some cases can be treated successfully with surgery, many patients are either not good candidates for surgery or may want to avoid or delay it if possible. There is a need for a treatment that reduces chronic joint pain and improves function yet avoids toxic effects of medications and the morbidity and mortality risks of surgery. One such option for these patients may be the intraarticular injection of hyaluronate.

Hyaluronate, a high molecular weight polysaccharide, is a principal component of synovial fluid and extracellular matrix of articular cartilage. It contributes to the elasticity and viscosity of synovial fluid. In addition to providing joint lubrication and shock absorbancy, hyaluronate helps to maintain the structural and functional characteristics of the cartilage matrix. It also inhibits the formation and release of prostaglandins, induces proteoglycan aggregation and synthesis, and modulates the inflammatory response (Frizziero, 1998). In $\mathrm{OA}$, the concentration and molecular weight of hyaluronate are reduced, limiting its role in maintaining normal joint biomechanics (Engström-Laurent A, 1997). Viscosupplementation with intraarticular injections of hyaluronate was approved by the Food and Drug Administration (FDA) in 1997 for treating pain associated with knee OA. Although the exact mechanism of action is not understood with certainty, recent research suggests that it exerts anti-inflammatory, analgesic, anabolic and possibly chondroprotective effects on the articular cartilage and joint synovium that reduce pain and disability and improve joint function. 
There are five injectable forms of hyaluronate approved for use in the United States, including Hyalgan, Supartz, Orthovisc, Synvisc and Euflexxa (Table 1). Each of these hyaluronate products differ in their origin, method of production, molecular weight, dosing instructions, rheologic properties, cost, pharmacodynamics and possibly clinical outcomes.

\begin{tabular}{|c|c|c|c|c|c|}
\hline Trade name & Hylagan & Synvisc & Supartz & Orthovisc & Euflexxa \\
\hline generic name & $\begin{array}{l}\text { sodium } \\
\text { hyaluronate }\end{array}$ & hylan G-F20 & $\begin{array}{l}\text { sodium } \\
\text { hyaluronate }\end{array}$ & $\begin{array}{l}\text { high molecular } \\
\text { weight } \\
\text { hyaluronan }\end{array}$ & $\begin{array}{l}\text { sodium } \\
\text { hyaluronate }\end{array}$ \\
\hline Year Approved & 1997 & 1997 & 2001 & 2004 & 2004 \\
\hline Source & $\begin{array}{l}\text { Rooster combs } \\
\text { (naturally } \\
\text { derived) }\end{array}$ & $\begin{array}{l}\text { Rooster combs } \\
\text { (chemically } \\
\text { modified, or } \\
\text { cross-linked) }\end{array}$ & $\begin{array}{l}\text { Rooster combs } \\
\text { (naturally } \\
\text { derived) }\end{array}$ & $\begin{array}{l}\text { Rooster combs } \\
\text { (naturally } \\
\text { derived) }\end{array}$ & $\begin{array}{l}\text { Bacterial } \\
\text { fermentation } \\
\text { (naturally } \\
\text { derived) } \\
\end{array}$ \\
\hline $\begin{array}{l}\text { Molecular } \\
\text { Weight } \\
\text { (kd) }\end{array}$ & $500-730$ & 6000 & $620-1170$ & $1000-2900$ & $2400-3600$ \\
\hline $\begin{array}{l}\text { Amount } \\
\text { per injection }\end{array}$ & $2 \mathrm{ml}$ & $2 \mathrm{ml}$ & $2.5 \mathrm{ml}$ & $2 \mathrm{ml}$ & $2 \mathrm{ml}$ \\
\hline $\begin{array}{l}\text { Active } \\
\text { ingredients per } \\
\text { injection }\end{array}$ & $\begin{array}{l}\text { 20mg sodium } \\
\text { hyaluronate }\end{array}$ & $\begin{array}{l}\text { 16mg sodium } \\
\text { hyaluronate } \\
\text { derivative }\end{array}$ & $\begin{array}{l}\text { 25mg sodium } \\
\text { hyaluronate }\end{array}$ & $\begin{array}{l}\text { 30mg sodium } \\
\text { hyaluronate }\end{array}$ & $\begin{array}{l}20 \mathrm{mg} \text { sodium } \\
\text { hyaluronate }\end{array}$ \\
\hline $\begin{array}{l}\text { Number of } \\
\text { injections per } \\
\text { cycle }\end{array}$ & 3 or 5 weekly & \begin{tabular}{|l|}
3 weekly \\
(In 2009, FDA \\
approved single- \\
dose Synvisc- \\
One $\mathrm{TM}^{\mathrm{TM}} 6 \mathrm{~mL}$ \\
injection for the \\
treatment of knee \\
OA)
\end{tabular} & 5 weekly & 3 or 4 weekly & 3 weekly \\
\hline
\end{tabular}

Table 1. Characteristics of five formulations of intraarticular Hyaluronans available in the United States

All products are manufactured from rooster combs except for Euflexxa, which is the only non-avian derived hyaluronan approved in the United States. Also, Synvisc undergoes additional chemical crosslinking to create hylans with increased molecular weight and increased elastoviscous properties. The differing molecular weights of the products lead to different half-lives; the half-life of Hyalgan or Supartz is estimated at 24 hours, while the half-life of Synvisc may range up to several days. There is no consistent evidence from well-controlled clinical studies that documents the superior efficacy of one product over another.

Although viscosupplementation is a well-established treatment option in knee OA and is included in the professional guidelines by European League of Arthritis \& Rheumatism (EULAR) and American College of Rheumatology (ACR), evidence regarding its use in ankle OA is limited. Recently, several studies attempting to evaluate the use of hyaluronate in the ankle have been published. In this chapter, we discuss our experiences, the indications, injection technique and review the clinical outcomes on hyaluronate use in 
patients with ankle OA. Additionally, future directions for the use of hyaluronate in the management of ankle OA and areas of active research in hyaluronate are discussed.

\section{Indications}

The exact indications for viscosupplementation are still evolving, but it currently can be considered for use in patients who have significant residual symptoms despite traditional nonpharmacologic and pharmacologic treatments. In addition, patients who have gastrointestinal or renal intolerance to NSAIDs, and those who wish to postpone surgical intervention or are poor candidates for surgery can be considered for these injections.

Contraindications to hyaluronate injection include protein/avian allergy (except Euflexxa), active skin disease and joint infections at the injection site. Patients with substantial venous or lymphatic stasis in the legs, bleeding disorder or treatment with anticoagulants are relatively contraindicated. Hyaluronate is not recommended to pregnant women, lactating women and children under 18, because the safety and effectiveness have not been established.

The ideal candidate for viscosupplementation has yet to be defined. Studies are inconclusive regarding the best responders with respect to age, level of OA as defined radiographically, level of symptoms and level of physical activity. We previously reported (Sun et al, 2006a) that patients with Kellgren-Lawrence grade 1and 2 ankle OA had good response to viscosupplementation (grade 1, doubtful narrowing of joint space and possible osteophytic lipping; grade 2, definite osteophytes and possible narrowing of joint space). This suggested that viscosupplementation was effective in mild to moderate ankle OA. Whether severe cases would likely respond to viscosupplementation remained unknown. In another case series by our study group (Sun et al, 2011), we stratified patients by age and radiographic severity to determine whether these factors would influence the treatment response. Subgroup analysis results showed that there was no significant difference in outcomes between patients with grade 2 and grade 3 OA in each study period. However, we found difference in clinical balance tests between patients of the younger age-group and the older age-group at different time points. As the subgroup analysis was not sufficiently powered, definite conclusion could not be drawn.

As the treatment group increases, the ideal subgroup of patients who are best candidates for ankle viscosupplementation should be identified.

\section{Injection technique}

In our experience, intraarticular injection of the ankle joint is easy to perform and requires no radiologic guidance. The two approaches for performing an ankle joint injection are the anterior medial and anterior lateral (Figure 1). For the anterior medial approach, we position the patient in the supine position, with the knee flexed and the foot flat on the examination table. The ankle is placed in a degree of plantarflexion, which opens the anterior aspect of the joint. We identify the space between the anterior border of the medial malleolus and the medial border of the tibialis anterior tendon and palpate this space for the articulation of the talus and tibia to locate a suitable entry point into the ankle joint. The injections are performed in aseptic conditions. We insert a 21-23 gauge needle into the identified space and direct posterolaterally to run parallel to the upper surface of the talus, which is slightly convex . Joint effusion, if present, should be aspirated before injection. Alternatively, the 
anterior lateral approach is done with the patient positioned with the foot in plantar flexion. The needle is inserted from the anterior lateral position and directed posteriorly toward the medial malleolus. The needle is advanced until there is a drop in tissue resistance confirming entry into the joint. Excessive weight bearing and strenuous activity are discouraged within 2 days following injection. Otherwise, no specific post-injection instructions are necessary.

Most injection in the ankle joint was performed without any instrumental guide in the literature. One of the limitations of hyaluronate therapy is that it can be difficult to ensure that intraarticular injections are actually given into the joint capsule. In clinical trials with ankle viscosupplementation, only one trial used a fluoroscopic guide for the injection (Cohen et al, 2008). Ultrasound has been used to guide hyaluronate injection in hip and hand OA, however, no ultrasound guide has been used in ankle OA studies. The aim for the future is to encourage the ultrasound-guided intraarticular injection because it is simple, fast, economic and safe; it does not require the use of contrast, allowing the intraarticular injection in patients intolerant to iodized contrasts. It can be repeated without limits, allows an easy visualization of fluid in the articular recess, the correct position of the needle and the distance from the vessels.

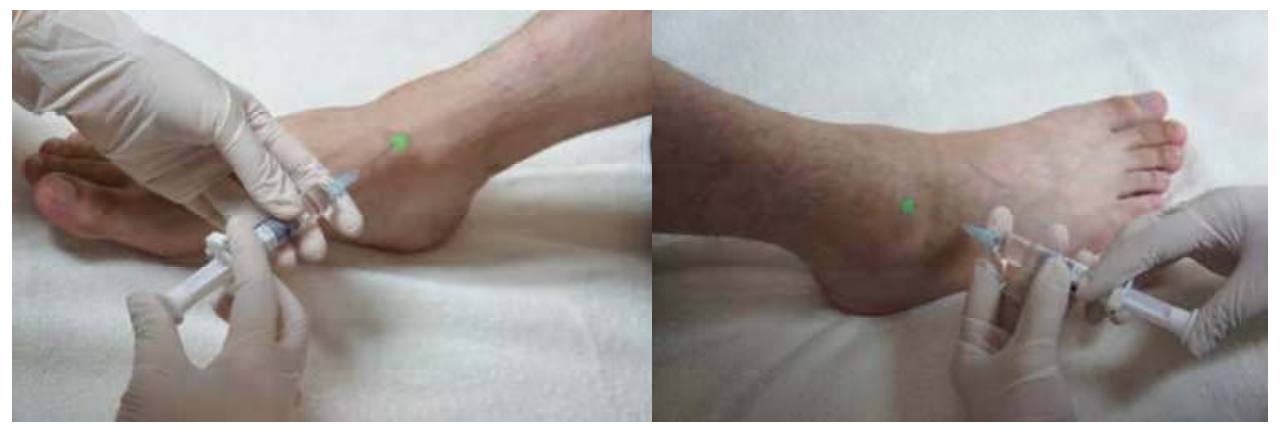

Fig. 1. The two approaches for ankle joint injection: the anterior medial and anterior lateral approaches

\section{Overview of clinical outcomes}

The potential for treating ankle OA by viscosupplementation has been suggested in the literature. To date, there are only 3 randomized controlled, double-blind trials ( Salt et al, 2006; Cohen et al , 2008; Karatosun et al, 2008) (Table 2) and a few case series in the search of the literature on viscosupplementation therapy for ankle OA (Table 3). Two recent reviews (Migliore et al, 2011; Sun et al, 2009) have provided an overview of clinical trials with hyaluronate therapy in ankle OA.

Salk et al. performed the first randomized, double-blind, saline solution-controlled trial in patients with grade 2, 3 and 4 (Kellgren-Lawrence) ankle OA (Salk et al, 2006), assessing the efficacy and safety of hyaluronate for the treatment of ankle OA. Patients were randomized to receive 5 weekly intraarticular injections of either $1 \mathrm{~mL}$ of sodium hyaluronate (10 $\mathrm{mg} / \mathrm{mL}$ ) or $1 \mathrm{~mL}$ of phosphate-buffered saline solution into the ankle joint. The primary outcome measure was the ankle osteoarthritis score (AOS) pain and disability assessment (Domsic and Saltzman, 1998). At 6-month follow-up, trends toward greater improvement in 
the hyaluronate group compared with sham injection control were noted. The benefit with hyaluronate in the treatment of ankle $\mathrm{OA}$ is consistent with previous published studies using hyaluronate in the knee.

\begin{tabular}{llll}
\hline Author Year Viscosupplement Study Patients & $\begin{array}{l}\text { Outcome } \\
\text { Measures }\end{array}$ & Outcomes \\
\hline
\end{tabular}

\begin{tabular}{|c|c|c|c|c|}
\hline $\begin{array}{l}\text { Salk et al } \\
(2006)\end{array}$ & $\begin{array}{l}\text { Hyalgan ( } 5 \\
\text { injections), } \\
1 \mathrm{ml} \text { per injection }\end{array}$ & $\begin{array}{l}17 \\
9 \text { HA } \\
8 \text { placebo }\end{array}$ & $\begin{array}{l}\text { AOS, } \\
\text { WOMAC pain } \\
\text { domain, } \\
\text { Ankle ROM, } \\
\text { Quality of life, } \\
\text { Rescue analgesic } \\
\text { consumption }\end{array}$ & $\begin{array}{l}\text { Safe and effective at } 6 \\
\text { months in patients } \\
\text { with Kellgren- } \\
\text { Lawrence grade 2-4 } \\
\text { ankle OA }\end{array}$ \\
\hline $\begin{array}{l}\text { Cohen MM } \\
\text { et al (2008) }\end{array}$ & $\begin{array}{l}\text { Hyalgan (5 } \\
\text { injections), } \\
2 \mathrm{ml} \text { per injection }\end{array}$ & $\begin{array}{l}30 \\
15 \text { HA } \\
15 \text { placebo } \\
\text { (saline control) }\end{array}$ & $\begin{array}{l}\text { AOS, } \\
\text { WOMAC, } \\
\text { Patient global } \\
\text { assessment, } \\
\text { SF-12 (short } \\
\text { form-12) }\end{array}$ & $\begin{array}{l}\text { Safe and effective for } 3 \\
\text { months }\end{array}$ \\
\hline $\begin{array}{l}\text { Karatosun et } \\
\text { al (2008) }\end{array}$ & $\begin{array}{l}\text { Adant ( } 3 \\
\text { injections), } \\
2.5 \mathrm{ml} \text { per injection }\end{array}$ & $\begin{array}{l}30 \\
15 \text { HA } \\
15 \text { progressive } \\
\text { ankle exercise }\end{array}$ & $\begin{array}{l}\text { AOFAS } \\
\text { ankle/hindfoot } \\
\text { score, } \\
\text { Gait quality, } \\
\text { VAS }\end{array}$ & $\begin{array}{l}\text { No statistical difference } \\
\text { between the exercise } \\
\text { and HA injection } \\
\text { groups in patients with } \\
\text { Kellgren-Lawrence } \\
\text { grade } 3 \text { ankle OA at } 12 \\
\text { months. }\end{array}$ \\
\hline
\end{tabular}

Abbreviations in the table:

HA=hyaluronic acid

AOS $=$ ankle osteoarthritis score

AOFAS $=$ American Orthopaedic Foot and Ankle Society

VAS $=$ visual analog scale

WOMAC $=$ Western Ontario and McMaster Universities Arthritis Index

Table 2. Randomized controlled trials of Viscosupplementation in the Treatment of Ankle Osteoarthritis 


\begin{tabular}{|c|c|c|c|c|}
\hline Author Year & Viscosupplement & Study Patients & $\begin{array}{l}\text { Outcome } \\
\text { Measures }\end{array}$ & Outcomes \\
\hline $\begin{array}{l}\text { Sun et al } \\
(2006)\end{array}$ & $\begin{array}{l}\text { Artz ( } 5 \text { injections), } \\
2.5 \mathrm{ml} \text { per injection }\end{array}$ & $\begin{array}{l}75 \\
75 \text { HA } \\
\text { N0 placebo }\end{array}$ & $\begin{array}{l}\text { AOS, } \\
\text { AOFAS } \\
\text { ankle/hindfoot } \\
\text { score, } \\
\text { Ankle ROM, } \\
\text { Patients' global } \\
\text { satisfaction, } \\
\text { Rescue } \\
\text { analgesics } \\
\text { consumption }\end{array}$ & $\begin{array}{l}\text { Safe and efficacious, } \\
\text { effects rapid at } 1 \text { week } \\
\text { post the fifth injection, } \\
\text { lasting for } 6 \text { months in } \\
\text { patients with Kellgren- } \\
\text { Lawrence grade } 1 \text { or } 2 \\
\text { ankle OA. } \\
\text { High patients' } \\
\text { satisfaction rate. } \\
\text { Significant reduction in } \\
\text { analgesics consumption }\end{array}$ \\
\hline $\begin{array}{l}\text { Witteveen } \\
\text { AGH et al } \\
(2008)\end{array}$ & $\begin{array}{l}\text { Sinvisc } \\
\text { (1 injections), } \\
2 \mathrm{ml} \text { per injection }\end{array}$ & $\begin{array}{l}51 \text { one } \\
\text { injection } \\
24 \text { 2nd injection } \\
\text { after 1-3 } \\
\text { months }\end{array}$ & $\begin{array}{l}\text { VAS, } \\
\text { AOS, } \\
\text { SF-36 }\end{array}$ & $\begin{array}{l}\text { Safe and effective for } 6 \\
\text { months in patients with } \\
\text { grade } 2 \text { ankle OA (van } \\
\text { Dijk et al scale). }\end{array}$ \\
\hline $\begin{array}{l}\text { Carpenter } \\
\text { et al (2008) }\end{array}$ & $\begin{array}{l}\text { Sinvisc ( } 3 \\
\text { injections), } \\
2 \mathrm{ml} \text { per injection }\end{array}$ & $\begin{array}{l}26 \\
14 \text { HA post } \\
\text { ankle } \\
\text { arthroscopy } \\
12 \text { ankle } \\
\text { arthroscopy }\end{array}$ & VAS & $\begin{array}{l}\text { The mean pain score of } \\
\text { the HA+arthroscopy } \\
\text { group was } 1 \text {, the score } \\
\text { for the arthroscopy } \\
\text { alone group was } 3 \text { on a } \\
10 \text { point VAS scale in } \\
\text { patients with Kellgren- } \\
\text { Lawrence grade } 2-4 \\
\text { ankle OA at } 3 \text { months, } \\
\text { with significant } \\
\text { difference. }\end{array}$ \\
\hline $\begin{array}{l}\text { Luciani } \\
\text { et al (2008) }\end{array}$ & $\begin{array}{l}\text { Sinvisc } \\
\text { ( } 3 \text { injections), } \\
2 \mathrm{ml} \text { per injection }\end{array}$ & $\begin{array}{l}21 \\
21 \text { HA } \\
\text { N0 placebo }\end{array}$ & AOS & $\begin{array}{l}\text { Significant } \\
\text { improvement in AOS } \\
\text { from baseline in } \\
\text { patients with Kellgren- } \\
\text { Lawrence grade } 2 \text { ankle } \\
\text { OA after } 6 \text { months, } \\
\text { effect maintained at } 12 \\
\text { and } 18 \text {-month follow- } \\
\text { ups }\end{array}$ \\
\hline $\begin{array}{l}\text { Mei-Dan } \\
\text { et al. (2010) }\end{array}$ & $\begin{array}{l}\text { Adant ( } 5 \\
\text { injections) } \\
2.5 \mathrm{ml} \text { per injection }\end{array}$ & $\begin{array}{l}13 \\
13 \text { HA } \\
\text { N0 placebo }\end{array}$ & $\begin{array}{l}\text { VAS, } \\
\text { AOFAS } \\
\text { ankle/hindfoot } \\
\text { score, } \\
\text { Ankle ROM }\end{array}$ & $\begin{array}{l}\text { Improvement of } 20 \% \text { in } \\
\text { the ROM, significant } \\
\text { reduction in VAS scale } \\
\text { and ankle-hindfoot } \\
\text { scores in patients with } \\
\text { Kellgren-Lawrence } \\
\text { grade } 2-4 \text { ankle OA for } 7 \\
\text { months }\end{array}$ \\
\hline
\end{tabular}




\begin{tabular}{|c|c|c|c|c|}
\hline Author Year & Viscosupplement & Study Patients & $\begin{array}{l}\text { Outcome } \\
\text { Measures }\end{array}$ & Outcomes \\
\hline $\begin{array}{l}\text { Sun et al } \\
(2011)\end{array}$ & $\begin{array}{l}\text { Hyalgan } \\
\text { ( } 3 \text { injections), } \\
2 \text { ml per injection }\end{array}$ & $\begin{array}{l}46 \\
46 \text { HA } \\
\text { N0 placebo }\end{array}$ & $\begin{array}{l}\text { AOS, } \\
\text { AOFAS } \\
\text { ankle/hindfoot } \\
\text { score, } \\
\text { Ankle ROM, } \\
4 \text { balance tests, } \\
\text { Patients' global } \\
\text { satisfaction, } \\
\text { Rescue analgesic } \\
\text { consumption }\end{array}$ & $\begin{array}{l}\text { Safe and effective, } \\
\text { improve physical } \\
\text { function and balance } \\
\text { with high patients' } \\
\text { satisfaction in patients } \\
\text { with unilateral } \\
\text { Kellgren-Lawrence } \\
\text { grade } 2 \text { or } 3 \text { ankle OA. }\end{array}$ \\
\hline
\end{tabular}

Abbreviations in the table:

$\mathrm{HA}=$ hyaluronic acid

AOS= ankle osteoarthritis score

AOFAS= American Orthopaedic Foot and Ankle Society

ROM=range of motion

VAS $=$ visual analog scale

Table 3. Case Series of Viscosupplementation in the Treatment of Ankle Osteoarthritis

Cohen et al. performed a randomized, double blind, saline solution-controlled trial of patients with grade 2, 3 and 4 (Kellgren-Lawrence) ankle OA (Cohen et al, 2008). Patients were randomized to receive 5 weekly injections of either $2 \mathrm{~mL}$ of sodium hyaluronate (Hyalgan) or $2 \mathrm{~mL}$ of phosphate-buffered saline solution in the ankle joint. All injections were fluoroscopically guided. The primary endpoint was pain on movement and weight bearing using the AOS 3 months after injection. At month 3, the patients in the hyaluronate group showed a significant improvement from baseline in AOS total score than those in the control group.

Karatosun et al. performed a prospective randomized trial with 12-months follow-up, to evaluate the efficacy of intraarticular injection of sodium hyaluronate (Adant ${ }^{\circledR}$ ) compared with exercise therapy (Karatosun et al, 2008). Patients with grade 3 (KellgrenLaurence) ankle OA were randomized to receive 3 weekly intraarticular injections of hyaluronate or an exercise cycle therapy, which included a series of progressive, isometric, isotonic range of motion, resistance, closed kinetic chain and proprioceptive exercise, for 6 weeks. Outcomes, including the American Orthopaedic Foot and Ankle Society (AOFAS) Ankle-Hind Foot score(Kitaoka et al,1994), gait, pain with VAS scale were evaluated and analyzed. At 12 months, both groups improve in pain score, walking surface, gait quality and total ankle-hind foot score. The authors concluded that the patients benefit either by 3 injection of hyaluronate or by 6 weeks of exercise therapy. The advantage of exercise therapy may be its non-invasive nature being preferred by both the physicians and the patients; however, while exercise therapy last 6 weeks, hyaluronate injections stop at 3 weeks. This point may be an advantage for the preference of hyaluronate injections.

In a relatively large case series by our group (Sun et al, 2006a), we reported outcomes of 75 patients with unilateral grade 1 or 2 (Kellgren-Lawrence) ankle OA. We concluded similarly that a regimen of 5 weekly intraarticular injection of sodium hyaluronate was safe and effective in the areas of pain and ankle function. Patients expressed a high level of 
satisfaction, with only relatively few local adverse events. These effects were rapid at 1 week post the fifth injection and could last for 6 months. One limitation in this trial includes the absence of a control group, thus the placebo effects associated with joint injections per se were not analyzed.

In the prospective case series by Witteveen et al, patients with symptomatic grade 2 (van Dijk et al scale) ankle OA ( $>50$ and $<90 \mathrm{~mm}$ on a $100 \mathrm{~mm}$ visual analog scale (VAS), were treated with intraarticular injection of Hylan GF-20 (Synvisc, $2 \mathrm{~mL}$ ) plus an optional second injection if pain remained at baseline level after 1, 2 or 3 months, with 6-9-months follow-up period (Witteveen et al, 2008). The primary efficacy endpoint was the change from baseline in the Pain VAS Score at 3 months. The results showed a statistically significant decrease in the mean Pain VAS score from $68.0 \mathrm{~mm}$ at baseline to $33.8 \mathrm{~mm}$ at month 3 . They reported that a regimen of one single intraarticular injection of hyaluronate (Synvisc), with the option of a second injection after 1-3 months if pain relief is inadequate, is an efficacious treatment of patients with symptomatic ankle OA.

Carpenter et al. conducted a controlled trial investigating the effectiveness of Hylan G-F 20 in reducing pain following ankle arthroscopy in patients with grade 2, 3 and 4 (KellgrenLaurence) ankle OA (Carpenter and Motley, 2008). Fourteen patients received 3 weekly injections of Hylan G-F 20 post ankle arthroscopy, while 12 patients received only ankle arthroscopy. At 3 months, the mean pain score of the Hylan G-F 20 plus arthroscopy group was 1 , while the score for the arthroscopy alone group was 3 on a 10 point VAS scale, and this difference was statistically significant.

In a case series by Luciani et al, 21 patients with a grade 2 (Kellgren-Laurence) ankle OA had 3 weekly intraarticular injections of $2 \mathrm{ml}$ of synvisc into the ankle joint (Luciani et al, 2008). The primary clinical outcome measurement was the AOS. The results showed significant improvement of the AOS from baseline after 6 months and this improvement was maintained at 12- and 18-month follow-ups.

Mei-Dan et al. have studied 16 patients with grade 2-4 (Kellgren-Lawrence) ankle OA who received intraarticular injections of $25 \mathrm{mg}$ of sodium hyaluronate for 5 consecutive weeks (Mei-Dan et al, 2010). There was a significant reduction in pain assessed by VAS scale and ankle-hindfoot scores and an improvement of $20 \%$ in the range of motion.

Previous ankle viscosupplementation studies reported that five weekly intraarticular injections of hyaluronate were safe and effective; however, the effect of three weekly injections has rarely been investigated. Our study group (Sun et al, 2011) conducted another prospective case series with a 6-month follow-up period and reported that three weekly injections of sodium hyaluronate are well tolerated, can provide pain relief, improve function and balance in patients with unilateral grade 2 or 3 (Kellgren-Lawrence) ankle OA. OA remains by far the most common disease of joints and represents a huge burden to society in terms of personal suffering and health resource utilization. The three-injection regimen may possibly represent a cost-saving therapy. Besides, pain associated with ankle OA may cause loss of balance, leading to falls, more injuries and higher costs to the patient and society. This study was the first that examined the effect of hyaluronate on balance in patients with ankle OA, as we had previously reported significant improvements in pain, physical function and balance tests after five weekly hyaluronate injections in geriatric patients with knee OA (Sun et al,2006b). Although the mechanism by which hyaluronate results in a clinical benefit in balance remains unknown and it remain an area important for future research, we thought pain reduction might be one of the major contributing factor. 


\section{Complications}

Because use of hyaluronate in the ankle is an "off label" application of this agent, patient safety is a key issue considering this treatment. Clinical studies have demonstrated that viscosupplementation is generally safe and well tolerated. Although significant complications are rare, mild adverse effects have been reported. Because there are no known hyaluronate-medication interactions, it is a good option for patients on multiple medications, particularly the elderly. Mild injection-site pain and swelling are the most common adverse events in the injected joints. These reactions are usually transient, resolving without intervention within 1 to 3 days. Other adverse events included rash, muscle cramps, dizziness, nausea, headache, local ecchymosis and pruritus. The overall incidence of adverse reactions in knee studies has been reported to be approximately $1 \%$ to $4 \%$. Rare cases of post-injection pseudogout with sodium hyaluronate and Synvisc have been reported. It is unclear whether these reactions were caused by the hyaluronate itself or by the injection procedure. There is growing evidence that Synvisc may be associated with an adverse event termed pseudosepsis or a severe acute inflammatory reaction. Pseudosepsis presents as severe inflammation of the joint, with a large effusion, and significant pain occurring within 1 to 3 days post injection. It requires symptomatic treatment, including use of modalities, activity modification, analgesics, and NSAIDs. Once infection has been excluded, intraarticular steroids may be of value. Despite a lack of understanding of both the etiology of pseudosepsis and the long-term effects of these local immunological reactions, such events would be expected to incur additional socioeconomic costs. Additional study is required to enable the treating physician to identify patients at risk for this injection related complication and to determine whether patients with a history of a pseudosepsis after hyaluronate injection can safely receive further hyaluronate therapy.

The safety in the treatment of ankle OA appears to be similar to the injections widely performed in the treatment of knee OA. No systemic adverse events were reported in the literature relating to ankle viscosupplementation; however, cases of local adverse reactions do exist. In study by Salt et al (Salk et al, 2006), injection site pain was noted in 5 $(29 \%)$ of the 17 patients, with no significant difference between the groups. In our case series (Sun et al, 2006a), local pain and erythema at the injection site occurred in 5 of 75 patients, it was mild and resolved within 48 hours without sequela. The adverse reaction rate was $5.3 \%$ per injection and $6.7 \%$ per patient. We observed that these adverse events sometimes occurred after several injections without any reaction previously, and sometimes they did not occur in subsequent injections. Interestingly, local adverse reactions did not predict treatment failure. All of these patient received subsequent injections and they still improved clinically and reported high satisfaction. The incidence of adverse events was also low in the study by Cohen et al (Cohen et al, 2008), only one case of pseudogout, resolved without therapy, was observed in the Hyalgan group. Witteveen et al (Witteveen et al, 2008) reported 35 patients $(63.6 \%)$ experienced a total of 89 adverse events in their study, which was relatively high compared with other studies. The majority of adverse events were arthralgia, injection site pain, and joint swelling, which were reported to be mild or moderate in intensity and transient in nature. Luciani et al. reported 11 patients (52\%) in their case series presented transient pain and erythema in the injection site that resolved within 2 days and did not interfere with remaining 
injections (Luciani et al, 2008). In the case series by Carpenter et al. (Carpenter and Motley, 2008), they did not observe any local or systemic adverse events.

\section{Further studies needed}

Despite the fact that hyaluronate has been proposed as a useful treatment of symptomatic knee OA, its role in the treatment of ankle OA is still not clear, due fundamentally to the dearth of large, well-controlled studies and to the methodologic limitations of those that have been published. Most studies included small cohorts, short follow-up periods and an overall level of evidence is low. The clinical effects of the hyaluronate products have considerable heterogeneity and therapeutic variability, as most studies use different dosages, injection frequencies, different outcome measures, especially at different time points. Conclusions regarding the clinical effectiveness of each hyaluronate product could not be drawn. There was no evidence for differential effects according to subgroups defined by age, gender, primary/secondary disease, body mass index/weight, or disease severity. The exact mechanisms of viscosupplementation action on osteoarthritic joints are uncertain. Although recent attention has focused on the disease-modifying potential of hyaluronate, especially the chondroprotective mechanism, definitive evidence is still lacking. We believe that hyaluronate can be used as an adjunct therapy, after failure of one or more courses of oral pain medications, or perhaps as a first choice in the treatment of ankle OA before prescription of pain medications.

Future studies regarding optimal dosing regimen, injection frequency and injection technique, optimal number of injections in a course of treatment, favorable prognostic factors, duration of benefits, effectiveness and safety of repeated courses of therapy, longer term trials, head-tohead comparisons of the various hyaluronate products, as well as the biochemical, morphologic, and histopathologic effects on cartilage are warranted. Cost-effectiveness needs to be addressed. Comparison studies or combination therapies with other treatment options, such as intraarticular steroid injections, NSAIDs and therapeutic exercise, are also needed to help determine the best overall treatment plan for patients with ankle OA.

\section{Conclusion}

The published data suggest that viscosupplementation may potentially be a safe and effective alternative in treating patients with ankle OA. However, there are still inadequate data to provide definitive conclusions on the efficacy of hyaluronate in reducing pain or improvement of function among patients with ankle OA. The FDA has not approved intraarticular hyaluronate for joints other than the knee. To date ankle viscosupplementation should only be used under careful supervision by the clinician. Many uncertainties on the use of hyaluronate remain. The use of standardized outcome measures is encouraged to facilitate meta-analyses and between trial comparisons. Additional studies are required before viscosupplementation should be included into the treatment paradigm for patients with ankle OA.

\section{References}

Carpenter B, Motley T (2008). The role of viscosupplementation in the ankle using Hylan GF-20. J Foot Ankle Surg 47(5):377-384 
Cohen MM, Altman RD, Hollstrom R, Hollstrom C, Sun C \& Gipson B (2008). Safety and efficacy of intra-articular sodium hyaluronate (Hyalgan) in a randomized, doubleblind study for osteoarthritis of the ankle. Foot Ankle Int 29(7):657-663

Domsic RT, Saltzman CL (1998). Ankle osteoarthritis scale. Foot Ankle Int 19(7):466-471

Engström-Laurent A. (1997) .Hyaluronan in joint disease. J Int Med 242:57-60.

Frizziero L, Govoni E \& Bachin P. (1998) Intraarticular hyaluronic acid in the treatment of osteoarthritis of the knee: clinical and morphological study. Clin Exp Rheumatol 16:441-9.

Karatosun V, Unver B, Ozden A, Ozay Z \& Gunal I (2008). Intraaticular hyaluronic acid compared to exercise therapy in osteoarthritis of the ankle. A prospective randomized trial with long-term follow-up. Clin Exp Rheumatol 26:288-294

Kitaoka HB, Alexander IJ, Adelaar RS, Nunley JA, Myerson MS \& Sanders M (1994). Clinical rating systems for the ankle-hind-foot, midfoot, hallux and lesser toes. Foot Ankle Int 15:349-353

Luciani L, Cadossi M, Tesei F, Chiariello E \& Giannini S (2008). Viscosupplementation for grade II osteoarthritis at the ankle: prospective study at 18 months' follow-up. Chir Organi Mov 92(3):155-160

Mei-Dan O, Kish B, Shabat S, Masarawa S, Shteren A, Mann G \& Nyska M.(2010). Treatment of osteoarthritis of the ankle by intra-articular injections of hyaluronic acid: a prospective study, J Am Podiatr Med Assoc, 100:93-100.

Migliore A, Giovannangeli F, Bizzi E, Massafra U, Alimonti A, Lagana B, Picchianti AD, Germano V, Granata M \& Piscitelli P. (2011). Viscosupplementation in the management of ankle osteoarthritis: a review. Arch Orthop Trauma Surg 131:139147.

Salk RS, Chang TJ, D'Costa WF, Soomekh DJ \& Grogan KA (2006). Sodium hyaluronate in the treatment of osteoarthritis of the ankle: a controlled, randomized, double-blind pilot study. J Bone Joint Surg Am 88(2):295-302

Saltzman CL, Salamon ML, Blanchard GM, Huff T, Hayes A, Buckwalter JA \& Amendola A. (2005). Epidemiology of ankle arthritis: report of a consectutive series of 639 patients from a tertiary orthopaedic center. Iowa Orthop J 25:44-6.

Sun SF, Chou YJ, Hsu CW, Hwang CW, Hsu PT, Wang JL, Hsu YW \& Chou MC (2006). Efficacy of intra-articoular hyaluronic acid in patients with osteoarthritis of the ankle: a prospective study. Osteoarthritis Cartilage 14:867-874

Sun SF, Hsu CW, Hwang CW, Hsu PT, Wang JL, Tsai SL, Chou YJ, Hsu YW, Huang CM \& Wang YL.(2006). Hyaluronate improves pain, physical function and balance in the geriatric osteoarthritic knee: a 6-month follow-up study using clinical tests. Osteoarthritis Cartilage, 14(7):696-701.

Sun SF, Chou YJ, Hsu CW \& Chen WL. (2009) Hyaluronic Acid as a Treatment for Ankle. Osteoarthritis. Curr Rev Musculoskelet Med, 2:78-82.

Sun SF, Hsu CW, Sun HP, Chou YJ, Li HJ \& Wang JL (2011). Efficacy of Three Weekly Intraarticular Injections of Hyaluronate on Pain, Function and Balance in Patients with Unilateral Ankle Osteoarthritis - a prospective study with 6 months followup. J Bone Joint Surg Am,; 93(18):1720-1726.

Thomas RH, Daniels TR. (2003). Ankle arthritis. J Bone Joint Surg Am. 85:923-36. 
Witteveen A, Giannini S, Guido G, Jerosch J, Lohrer H, Vannini F, Donati F, Schulz A, Scholl J, Sierevelt I \& van Dijk N (2008). A prospective multi-centre, open study of the safety and efficacy of hylan G-F 20 (Synvisc ${ }^{\circledR}$ ) in patients with symptomatic ankle (talocrural) osteoarthritis. Foot Ankle Surg 14:145-152 


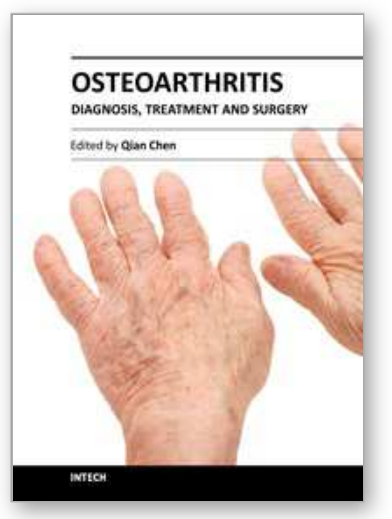

\author{
Osteoarthritis - Diagnosis, Treatment and Surgery \\ Edited by Prof. Qian Chen
}

ISBN 978-953-51-0168-0

Hard cover, 404 pages

Publisher InTech

Published online 02, March, 2012

Published in print edition March, 2012

Osteoarthritis is one of the most debilitating diseases affecting millions of people worldwide. However, there is no FDA approved disease modifying drug specifically for OA. Surgery remains an effective last resort to restore the function of the joints. As the aging populations increase worldwide, the number of OA patients increases dramatically in recent years and is expected to increase in many years to come. This is a book that summarizes recent advance in OA diagnosis, treatment, and surgery. It includes wide ranging topics from the cutting edge gene therapy to alternative medicine. Such multifaceted approaches are necessary to develop novel and effective therapy to cure OA in the future. In this book, different surgical methods are described to restore the function of the joints. In addition, various treatment options are presented, mainly to reduce the pain and enhance the life quality of the OA patients.

\title{
How to reference
}

In order to correctly reference this scholarly work, feel free to copy and paste the following:

Shu-Fen Sun, Chien-Wei Hsu, Yi-Jiun Chou, Yu-Nong Wang and Mei-Chia Chou (2012). Hyaluronate for the Treatment of Ankle Osteoarthritis, Osteoarthritis - Diagnosis, Treatment and Surgery, Prof. Qian Chen (Ed.), ISBN: 978-953-51-0168-0, InTech, Available from: http://www.intechopen.com/books/osteoarthritis-diagnosistreatment-and-surgery/hyaluronate-for-the-treatment-of-ankle-osteoarthritis

\section{INTECH}

open science | open minds

\author{
InTech Europe \\ University Campus STeP Ri \\ Slavka Krautzeka 83/A \\ 51000 Rijeka, Croatia \\ Phone: +385 (51) 770447 \\ Fax: +385 (51) 686166 \\ www.intechopen.com
}

\author{
InTech China \\ Unit 405, Office Block, Hotel Equatorial Shanghai \\ No.65, Yan An Road (West), Shanghai, 200040, China \\ 中国上海市延安西路65号上海国际贵都大饭店办公楼 405 单元 \\ Phone: +86-21-62489820 \\ Fax: $+86-21-62489821$
}


(C) 2012 The Author(s). Licensee IntechOpen. This is an open access article distributed under the terms of the Creative Commons Attribution 3.0 License, which permits unrestricted use, distribution, and reproduction in any medium, provided the original work is properly cited. 